\title{
ON THE EXCITATION OF LOCAL ELECTRIC CURRENT IN THE BIOLOGICAL ENVIRONMENT
}

\begin{abstract}
The subject of the study in the article is to study the method of excitation of human body tissues using an electric current. The purpose of the work is to develop a method for exciting local current in a human body affecting the microcirculation of blood and excitability of local areas of muscle tissue during the treatment process. The article solves the following tasks: the creation of a model pattern of fabric, the rationale for the generation of electric current inside the sample, the development of the design of the current generation system and measuring the electrical response of the model sample of the tissue on the occurrence of electric current, determining the size and spatial current distribution in the model sample of the fabric, comparison The obtained current values with known and admissible in medical practice its values, determination of the advantages of the proposed method of excitation of current compared to the traditional used in medicine. The following methods were used: analysis of scientific publications for the subject of the study, the calculation of the expected current parameters in the model sample, the method of designing the nodes of the current generation and measurement system of the electrical response, the experimental method of excitation of the current and measuring the sample response to it. The following results were obtained: a new acoustic-magnetic method of exciting electric current in local areas of muscle tissue is justified, which allows determining for them the optimal values of the therapeutic current and the value of its threshold value. model samples of muscle tissue are created, a magnetohydrodynamic method of generating electric current inside the patient's body is justified, design of a system for generating current and measuring the electrical response of a model fabric sample to the occurrence of electric current in it; determining the magnitude and spatial distribution of the current in the model fabric sample; comparison of obtained current values with known and permissible values in medical practice and proved their safety for a person. Calculated ratios are obtained, which connect value of excited local current with parameters of ultrasonic radiation, external permanent magnetic field and biological medium. The materials have been found that the current density excited in the local area of the biological medium is independent of the ultrasound frequency and is determined mainly by the intensity of the ultrasound and the constant magnetic field. The advantages of the current excitation method according to the present invention over the conventional galvanic method of passing current through the patient's skin are the ability to generate current in any desired local area of the patient's tissue and its complete safety. Conclusions: The scientific foundations of the new method of excitation of local current inside the human body have been developed and experimentally tested on model samples. Using this method can significantly increase the effectiveness of the treatment process based on the effect of current on blood microcirculation in predetermined areas of muscle tissue and for the first time will allow distinguishing and determining with high accuracy thresholds of their excitability by electric current.
\end{abstract}

Keywords: blood microcirculation, threshold of muscle tissue excitability; tissue model; magnetic hydrodynamics of conducting solution; ultrasound; local electric current.

\section{Introduction}

Physical and chemical phenomena caused by the magnetohydrodynamic effect and electric current through a conductive biological environment (BE) are widely used in modern medicine for diagnosis and therapy $[1,2,3,4$, $5,6]$. These phenomena, in particular, include: electrophoresis of the ions of drugs of drugs through human skin in a constant magnetic field (CMF); measurement of the flow rate of blood in the magnitude of the electric field generated by it in the PMP during the pulse filling of the blood vessel; braking of blood current in vessels under the action of a large PMP; therapeutic galvanization of muscle tissue by passing a constant electrical current of low density through the patient's skin from the external high-voltage $(80 \mathrm{~V})$ voltage source; strengthening the microcirculation of blood and the definition of the first threshold of the validity of the current in the muscular tissue by passing an alternating electric current through the skin of the patient. All these phenomena occur either due to the natural movement of blood ions and plasma under the action of the ambient heat or the activity of the heart, or when the transport current is supplied to the $\mathrm{BE}$ from the external voltage source.

Recently, the study of the movement of electric and magnetic particles in the magnetic field under the influence of ultrasonic radiation (USR) has begun in BE. In particular, for the first time, the value of the electric field strength arising in the model electro conductive sample BE under the joint action of ultrasound and CMF [7] was measured. Also, for the first time, an acoustic-magnetic method (AMM) of acting on a model BE sample containing magnetic nanoparticles was proposed and investigated in order to determine the possibility of high-precision measurement of their concentration in the pathological focus of $\mathrm{BE}$ with the target delivery of therapeutic preparations to it [9].

One of the topical problems of medicine is to study the excitability of human body tissues, which is associated with changes in the membrane cell potential and the condition of blood microcirculation and lymph in tissues. One of the ways of influencing the excitability of muscle tissue and human organs is transmitting an alternating electric current through it. In this case, an important measurable indicator of tissue excitability is the first threshold for the sensibility of the transmitted current. The traditional and common method of transmitting current through the muscle tissue is the use of an electrical circuit from an adjustable voltage generator, the input wire connecting one of the terminals of the generator with the skin of the patient through the clamping electrode at a particular point of the body and 
the output wire connecting the other point to the other point on the patient's skin with the second output of the generator [6]. The gap of one of the wires includes an ammeter, according to which the magnitude of the first threshold current is measured when the patient is sensitive to the patient's appearance of the muscles. This method of determining the threshold current and therapeutic current corresponding to the optimal level of blood circulation has an important disadvantage that affects the informativeness of their measurement. This is caused by the fact that the current through the muscles with this method is not spatially homogeneous. Its density is maximum in the area of the supply electrodes and decreases when removing them. In addition, when passing in the field of internal organs, this inhomogeneity increases, as they have different electrical resistance. As a result, the amount of therapeutic current and the measured threshold current are averaged throughout the muscular volume and do not correspond to their local values for one or another organ or a particular area of even homogeneous muscle tissue. Therefore, the development of a new non-integrated method is required to establish the amount of therapeutic current and measuring its threshold value. The new method should allow to establish the optimal local values of the therapeutic current for various sections of the human body and measure the values of the threshold current in them.

The purpose of this work is to substantiate the possibility of creating a new local excitation method using AMM in a given BE section of an alternating electric current, eliminating the need for its contact (galvanic) transmission through the skin of the patient and does not have drawbacks of this traditional flow of current formation through the patient's body.

\section{Model system for generating an electric field in $\mathrm{BE}$ with AMM}

For the existence of an electric current in any environment, it is necessary to have an electric field in it. Figure 1 shows a schematic diagram of a system that allows exciting using AMM and measure the variable with a frequency of USR electric field of the BE model in the form of a solution placed in a cylindrical vessel. A low-conductive $\mathrm{NaCl}$ solution in water, having a density, viscosity and electrical conductivity, close in magnitude to the BE parameters $[6,10]$.

With the effect of USR with frequency $f$ on the upper part of the solution along its height (in the direction of the $\mathrm{Z}$ axis in fig. 2), a wave of compression and expansion propagates. The counter wave reflected from the bottom of the vessel interferes with the incident wave If the distance from the bottom of the vessel to the emitter USR (h) is equal to an integer $(n)$ of the lengths $(\lambda)$ of sound waves $(h=n \lambda)$, then the so-called standing wave [11] is installed in the vessel. The velocity distribution $\mathrm{VZ}$ of the solution particles in the standing wave is as shown in fig. 2.

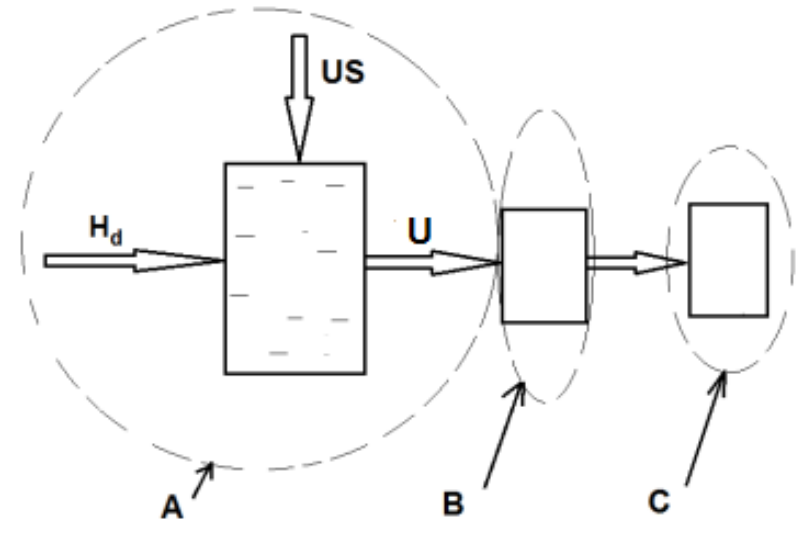

Fig. 1. Circuit diagram of blocks (A, B, C) systems for excitation of local current in a model sample of a biological environment. Block A includes a model sample, to which an external constant magnetic field (B) and ultrasound radiation (US) and which generates an alternating voltage (U). Block B serves to measure the voltage $\mathrm{U}$, and the block $\mathrm{C}$ is a voltage registrar $\mathrm{U}$.

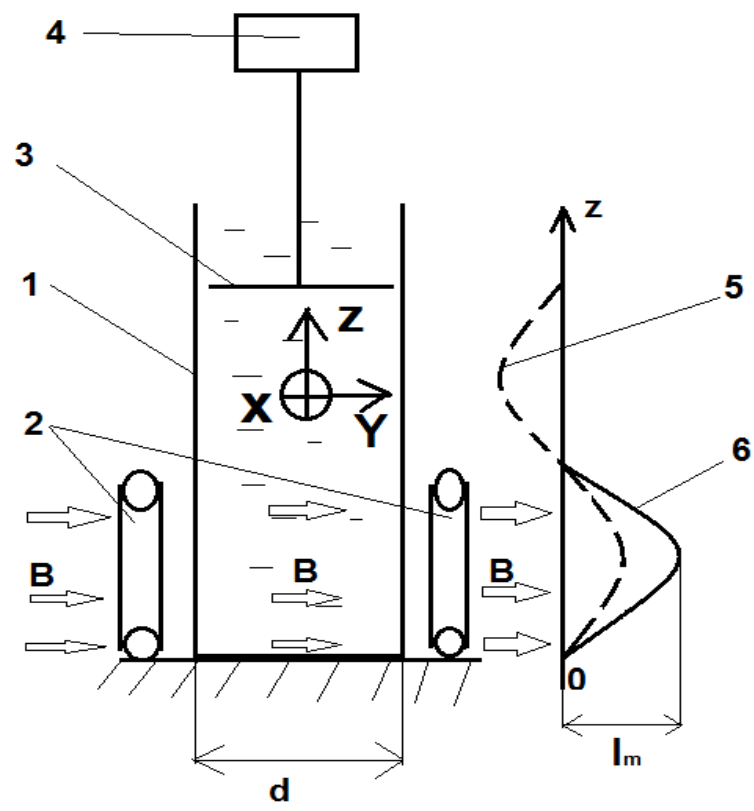

Fig. 2. Functional scheme of the system for the implementation of acoustic-magnetic excitation of electric current in the $\mathrm{BE}$ model sample in the form of a solution of $\mathrm{NaCl}, 1$ - vessel with a solution, $2-$ Helmholtz coils to create a magnetic field with induction $\mathrm{B}=\mathrm{m}_{0} \mathrm{H}_{\mathrm{d}}, 3$ - round flat radiator ultrasound, 4 Ultrasound generator, 5 - distribution of velocity $V_{z}$ movement into the solution under the action of sound (dash line), 6 current distribution (I) in solution, $\mathrm{m} 0=4 \pi 10^{-7} \mathrm{Gn} / \mathrm{m}$.

With the simultaneous action of the USR and a constant magnetic field BY on the solution, directed perpendicular to the direction of propagation of the USR along the $\mathrm{Y}$ axis, an alternating electric field with an intensity EX appears in it $[7,8]$ in accordance with the relation known from magnetohydrodynamics:

$$
E_{x}=V_{z} \times B_{y}=E_{m x} \sin 2 \pi f=V_{m z} \sin 2 \pi f \times B_{y},
$$

where $E_{m x}, V_{m z}$, - the amplitude of the electric field strength and the velocity of the solution. In this case, the 
EX direction is perpendicular to both the direction of induction of the field $B_{y}$ and to the direction $V_{z}$. To measure the distribution of the EX value at different points of the vessel, which means that in different sections of the standing wave in the solution, two (or more) metal measuring probes are placed with a distance (base) $L$ between them. The value of EX can be represented by the derivative of the electric potential $U$ in the direction $x$ :

$$
E_{x}=\frac{d U}{d x} \approx \frac{\left(U_{2}-U_{1}\right)}{L}
$$

where $\left(U_{2}-U_{1}\right)$ - The potential difference at two points $(1,2)$ of the solution located at a distance $L$ along the $X$ axis. The potential difference (voltage) on probes can be measured by a voltmeter of alternating voltage. Calculations [7] show that the value of the maximum voltage $U_{m}$ on probes is described by the formula:

$$
U_{m}=E_{m x} \times L=\left[\frac{2 P}{c \rho_{1}}\right]^{0,5} B_{y} \times L,
$$

where $\left[\frac{2 P}{c \rho_{1}}\right]^{0,5}=V_{m X}$, and $P, c, \rho_{1}$ is the intensity (power) of USR, speed of sound in solution, density of solution.

Fig. 2 shows a detailed functional diagram of a model system for studying the electrical properties of the BE sample in magnetic and acoustic fields, as well as the spatial distributions of the velocity $V_{z}$ of the solution displacement under the action of USR along the direction $\mathrm{Z}$ of USR propagation and the excited electric current I. This figure also shows the source constant magnetic field with induction BY in the area of solution in the form of two Helmholtz coils (2), USR generator (4), cylindrical vessel with a model solution (1), USR emitter (3) generating sound along the $Z$ axis of the vessel. The different polarities of the maxima $\mathrm{E}$ along the height of the vessel correspond to the places of maximum compression and extension of the solution under the action of the USR standing wave. Note that a similar picture of the appearance of a standing wave can take place if the USR "beam" is passed through the human body, since an incident sound wave on the skin on one side of the body will be reflected in the same way from the skin on the opposite side of the body.

To obtain the maximum voltage value on probes, it is necessary to arrange the probes in the maximum $E_{X}$ region. As is known [11], the length of a standing wave is equal to the length $(\lambda)$ of the wave of sound in the studied medium and is given by the expression:

$$
\lambda=\frac{c}{f}
$$

where $c$ is the sound speed in solution.

Thus, changing the frequency of USR, it is possible to change the distribution of the $E_{X}$ in the vessel and have two or more maxima of the electric field strength of different polarity along the direction of the propagation of the sound in it (fig. 3).

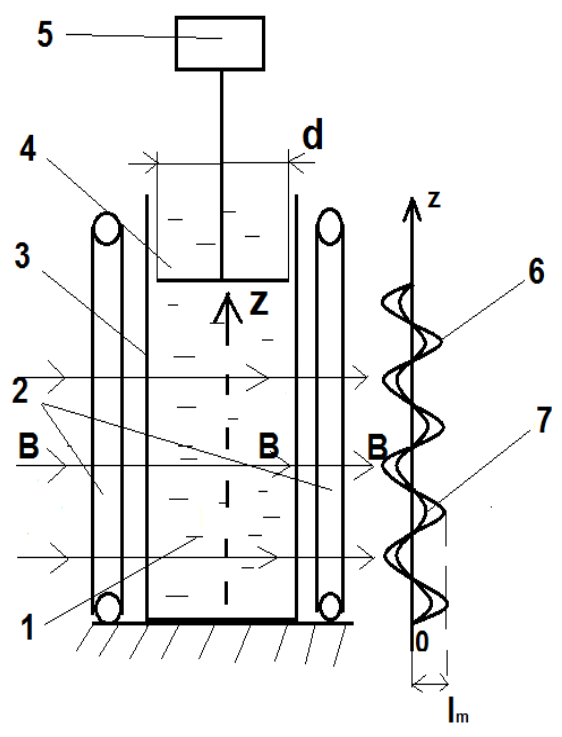

Fig. 3. Functional diagram of the system for excitation with AMM of the "chain" of sections of electric current excitation in a solution (1) simulating a biological environment, 2 - Helmgltz coils, 3 - cylindrical vessel with a solution with an inner diameter d, 4 - flat round USR emitter with a diameter d, 5 USR generator, 6 - distribution of the solution velocity under the action of USR, 7 - distribution of the magnitude of the excited current in local areas of the solution.

The periodic change in the electric field intensity in space results in a periodic change in the potential difference along the height of the vessel and a corresponding periodic change in the current value flowing in various zones of the electro conductive solution located along the length of the vessel and according to the Ohm law inversely proportional to the electrical resistance of the solution (or biological real medium). Materials A sufficiently large distance between current maxima, equal to half the wavelength of the low frequency USR, allows to create one (as in figure 2) or several (as in Figure 3) current zones spaced in space along the axis of the vessel, which in the real BE will act on its different sections with different excitability. For example, at a USR frequency of $22 \mathrm{kHz}$, the length of the sound half wave is about $30 \mathrm{~mm}$ in water (and in a near-density BE).

As can be seen in fig. 2, localization in a solution with an electric current, having a length along the $\mathrm{z}$ axis equal to one half-period of the standing wave, can be organized by the spatial localization of the CMF action per solution (or to the patient's body site). To do this, it is necessary to use the source of the local magnetic field as a permanent magnet or coils with a current having dimensions that do not exceed half the length of the standing wave in the vessel. Only in this part of the vessel (or patient) will there be an electric current as a result of the use of AMM. The weakening or absence of a magnetic field in the rest of the vessel leads to the practical absence of an electric field in it in accordance with formula (1) due to the absence of the cause (magnetic field) of the occurrence of the electric current. At the same time, the 
permissible distance from the local CMF source to the current generation in the real situation, i.e. when the current is excited in the patient's body, it should not significantly exceed the size (aperture) of the field source. This is due to an increase in the inhomogeneity of the magnetic field of scattering of the local source as it removes from it and with a decrease in its value, and hence, with a decrease in the generated current. It follows from this that the maximum depth of the location in the patient's body of a single area with a current having about $30 \mathrm{~mm}$ (at a frequency of USR about $20 \mathrm{kHz}$ ) can be no more than $50-100 \mathrm{~mm}$.

To create a patient in a patient several sections ("chains") with a current along the USR "beam" (as in fig. 3, at a frequency of USR 4 times higher compared to fig. 3), the formation of a homogeneous $\mathrm{CMF}$ on the entire length of these sections is necessary.

This can be done using a Helmholtz coil with a diameter somewhat large than the height of the model vessel and, accordingly, large than the size of the patient's body section in the actual situation of the use of AMM in medical practice. It uses one of the advantages of USR (compared with the electromagnetic field of high frequency), which practically does not fade at distances characteristic of the sizes of the human body. Therefore, when using AMM restrictions on the location of the processed current of the BE region does not exist. With an increase in frequency only decreases the length of the areas with an excited current in their "chain" located along the USR "beam".

\section{Calculation of an electric current excited in BE model with AMM}

The calculation of an AMM-excited current in BE was carried out on the basis of experimentally obtained potential difference values on two copper probes introduced into the $\mathrm{NaCl}$ model solution [7, 12]. The diagram of the measuring system is shown in fig.4.

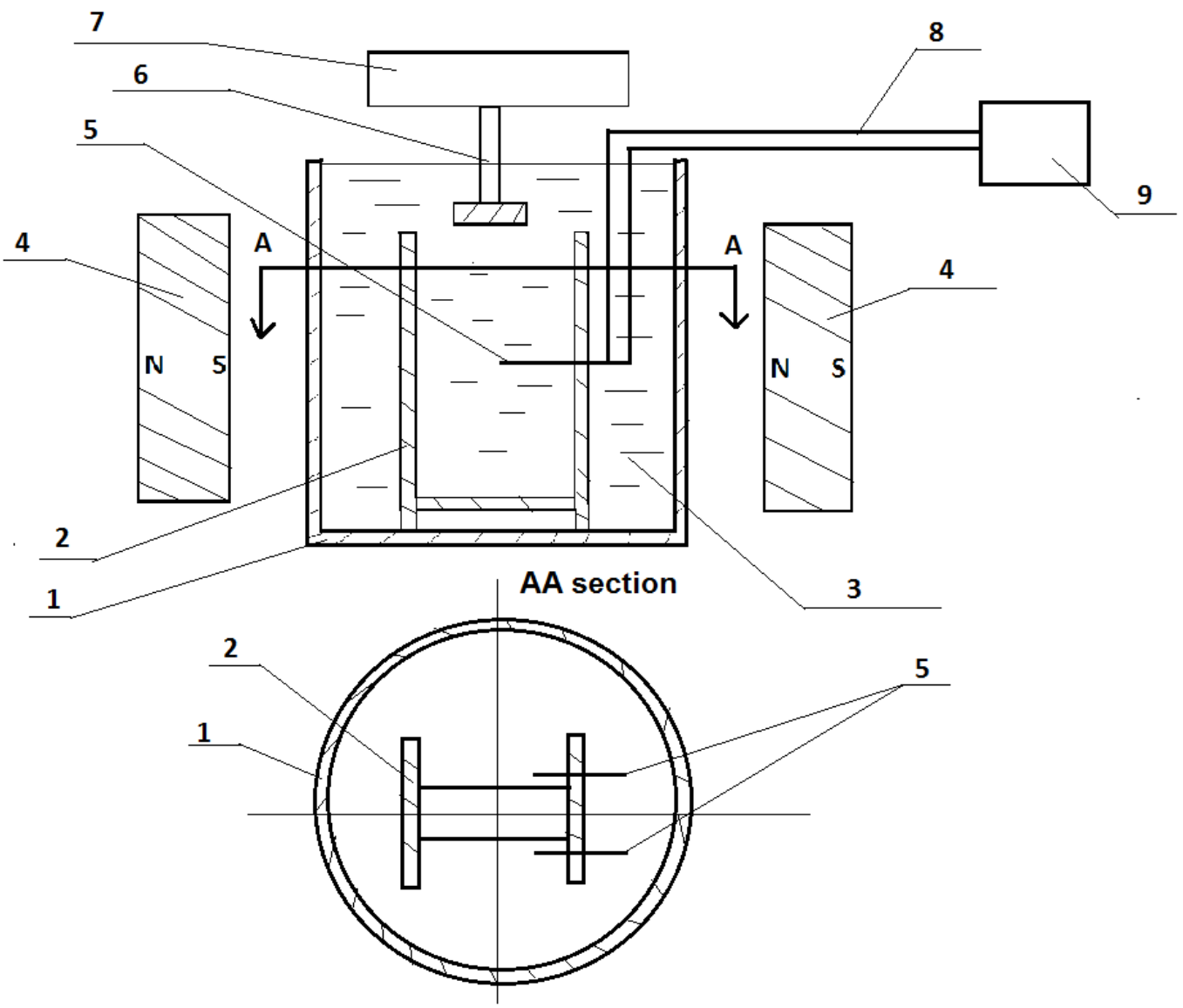

Fig. 4. Measuring system diagram: 1 - copper cup, 2 - plates for fixing electrical probes, 3 - $\mathrm{NaCl}$ solution, 4 - permanent magnets, 5 - electrical probes, 6 - sonic conduit of the USR source, 7 - USR generator, 8 - wires from probes to voltmeter, 9 - selective microvoltmeter.

The probes with a length of $1 \mathrm{~cm}$ and a distance between them $L=1 \mathrm{~cm}$ were located approximately in the region of the maximum distribution of the electric field strength at a power of USR $0.01 \mathrm{~W} / \mathrm{cm}^{2}$ at a frequency of $22 \mathrm{kHz}(\lambda=6.8 \mathrm{~cm})$. One standing wave period was located at the distance between the USR source and the bottom of the vessel with the solution. The value of the
CMF, created by two permanent magnets with a diameter of $45 \mathrm{~mm}$, in the area of the probes was equal to $0.4 \mathrm{~T}$. The amplitude of the voltage Um across the probes was $5 \times 10^{-5} \mathrm{~V}$. The region of the main part of the current flowing between the probes can be approximately represented as a cube with sides equal to $1 \mathrm{~cm}$, since equal to the diameter (d) of the USR "beam", and its average 
length ( $\lambda / 4)$ along the $\mathrm{Z}$ axis are also about $1 \mathrm{~cm}$. For the $\mathrm{BE}$ averaged resistivity at low frequencies equal to $\rho 2=$ $140 \mathrm{Ohm} \mathrm{cm}[6,10]$, assuming that the resistance is mainly active, it can be calculated using Ohm's law the amplitude of the current Im through the BE specified region:

$$
I_{m}=\frac{U_{m}}{R}=\frac{U_{m}}{\rho_{2} d /(\lambda / 4) d}=\frac{V_{m z} B_{y} d}{\left({ }^{4} \rho_{2} / \lambda\right)}=\frac{c V_{m z} B_{y} d}{\left(4 \rho_{2} f\right)},
$$

where $R$ - current flow area resistance. Substituting the value for the velocity $V_{m z}$ into formula (5), we obtain:

$$
I_{m}=\frac{c\left[2 P / c \rho_{1}\right]^{0,5} B_{y} d}{4 \rho_{2} f} .
$$

For the maximum current density jm, from (5) and (6) we obtain:

$$
j_{m}=\frac{I_{m}}{(\lambda / 4) d}=\frac{I_{m} f}{c d}=\frac{\left[2 P / c \rho_{1}\right]^{0,5} B_{y}}{\rho_{2}} .
$$

It follows from (7) that the density of the excited local current does not depend on the USR frequency. After substituting the numerical values of the parameters into formula (6), we obtain $I_{m}=0,5 \cdot 10^{-6} \mathrm{~A}$. In this case, the maximum current density jm in such a local BE model region was $j_{m}=0,5 \cdot 10^{-6} \mathrm{~A} / \mathrm{cm}^{2}$. According to medical standards [6], the maximum permissible harmless current density passed for therapeutic purposes through biological tissues and human organs should not exceed $0.5 \mathrm{~mA} / \mathrm{cm}^{2}$ $=0.5 \times 10^{-3} \mathrm{~A} / \mathrm{cm}^{2}=5 \times 10^{-4} \mathrm{~A} / \mathrm{cm}^{2} \ldots$

If it is necessary to generate current densities greater than $j_{m}=0,5 \cdot 10^{-6} \mathrm{~A} / \mathrm{cm}^{2}$ using AMM, the value of the electric field EX excited in BE should be increased.

According to formula (7), this can be achieved primarily by increasing the USR intensity and CMF value within acceptable limits. From the point of view of medical safety (to exclude BE cavitation), the USR power should not exceed $1 \mathrm{~W} / \mathrm{cm}^{2}$ [11]. A constant magnetic field, provided the patient is in a static position in this field, can be very large ( 7 or more Tesla) $[13,14,15]$. With the indicated values of the permissible lowfrequency USR intensity and with a CMF equal to 7T, it follows from formula (7) that in a local area of the biological environment with a USR beam diameter of $1 \mathrm{~cm}$, a current with a maximum density of about 10-4 A/ $\mathrm{cm}^{2}$ can be excited. The regulation of the current density in the local sections of BE can occur over a wide range by changing the power USR or the value of the CMF

The main advantages of generating alternating current through BE using AMM over the traditional galvanic method of passing current through the patient's skin are:

1) the possibility of exciting electric current in local, predetermined areas of the biological environment:

a) in the form of a single region with a characteristic size of about $30 \mathrm{~mm}$ and with a maximum alternating current density in it up to $10^{-4} \mathrm{~A} / \mathrm{cm}^{2}$ (which is five times less than the permissible and dangerous value for humans) at a frequency of about $20 \mathrm{kHz}$ with a CMF source aperture no more half wavelength USR (about $30 \mathrm{~mm}$ );

b) in the form of several amplitude-modulated current regions with the size of each of them equal to half the length of the USR standing wave in the patient's body and located in a uniform magnetic field;

2) the safety of the proposed equipment for creating local areas with current due to the absence of sources of increased electrical voltage in it.

\section{Conclusions}

A new, more informative and safe method of creating an electric current in the human body for medicinal purposes has been proposed and substantiated. The method is based on the excitation of an electric current in a local area of the body using the acoustomagnetic method (AMM). To substantiate this method, computational and experimental studies were performed on model samples of a biological environment. A calculated relationship is obtained that connects the magnitude of the excited current with the parameters of the ultrasonic and magnetic fields, as well as with the parameters of the model sample. The calculated ratios are verified by comparison with experimental results. The local density of the excited current in the experimental model sample was calculated and the possibility of reaching a current density at the level of $10^{-4} \mathrm{~A} / \mathrm{cm}^{2}$, which is close to the maximum permissible value for the human body, $5 \times 10^{-4} \mathrm{~A} / \mathrm{cm}^{2}$ ) was shown.

\section{References}

1. Abakumov, V. G., Gotra, Z. Y., Zlepko, S. M. and others. (2010), Optoelectronic medical systems [Optoelektronni medychni systemy], Vinnytsia : UNIVERSUM-Vinnytsia, $329 \mathrm{p}$.

2. Kizimova, N. N. (1991), "Magnetohydrodynamic effects during blood movement" ["Magnitogidrodinamicheskiye effekty pri dvizhenii krovi"], Biophysics, Vol. 36, No. 1, P. 147.

3. Belousova, L. E. (1965), "On the possibility of inhibition and stopping of blood by a magnetic field" ["O vozmozhnosti tormozheniya i ostanovki krovi magnitnym polem"], Biophysics, Vol. 10, No. 2, P. 365-366.

4. Vardanyan, V. A. (1973), "Influence of a magnetic field on blood flow" ["Vliyaniye magnitnogo polya na techeniye krovi"], Biophysics, Vol. 18, No. 3, P. 491-496.

5. Karchevsky, E. M., Marochnik, L. S. (1965), "On the hydrodynamic variant of blood movement" ["O gidrodinamicheskom variante peremeshcheniya krovi"], Biophysics, Vol. 10, No. 3, P. 371-373. 
6. Oleinik, V. P. (2006), Fundamentals of the interaction of physical fields with biological objects [Osnovy vzaimodeystviya fizicheskikh poley s biologicheskimi ob"yektami], Kharkiv, KhAI.

7. Avrunin, O. (2019), "Acoustic excitation of electric field in water solution NaCl", Przeglad elektrotechniczny, No. 1 (4), P. 160-163. DOI: https://doi.org/10.15199/48.2019.04.28

8. Rosa, R. (1979), Magnetohydrodynamic energy conversion [Magnitogidrodinamicheskoye preobrazovaniye energii], Moscow, $252 \mathrm{p}$.

9. Bondarenko, I. S., Avrunin, O. G., Rakhimova, M. V., Bondarenko, S. I., Krevsun, A. V., Kulish, S. M. (2019), "Acoustomagnetic Registration of Magnetic Nanoparticles in a Liquid Medium", Telecommunications and Radio Engineering, Vol. 78 (8), P. 707-714.

10. Berezovsky, V. A., Kolotilov, A. M. (1990), Biophysical characteristics of human tissues [Biofizicheskiye kharakteristiki tkaney cheloveka], Kyiv, Naukova Dumka.

11. Elpiner, I. E. (1963), Ultrasound. Physicochemical and biological action [Ul'trazvuk. Fiziko-khimicheskoye $i$ biologicheskoye deystviye], Moscow : Fizmatgiz, 420 p.

12. Bondarenko, I. S., Avrunin, O. G. (2017), "Magnetic hydrodynamics of the biological environment, Actual problems of automation and instrumentation" ["Magnitnaya gidrodinamika biologicheskoy sredy, Aktual'nyye problemy avtomatiki i priborostroyeniya"] : materials of the 1st International scientific and technical conference, P. 252.

13. Chizhik, V. I. (2009), Quantum Radiophysics. Magnetic resonance and its applications, St. Petersburg University, 700 p.

14. Wang, X. L., Ghorbani, R., Peleckis, G., Dou, S. X. (2008), "Very high critical field and superior Jc-field performance in NdO0.82F0.18FeAs with Tc of 51 K", arXiv:0806.0063 (31 May 2008).

15. Hunte, F., Jaroszynski, J., Gurevich, A., Larbalestier, D. C., Jin, R., Sefat, A. S., McGuire, M. A., Sales, B. C., Christen, D. K., Mandrus, D. (2008), "Two-band superconductivity in LaFeAsO0.89F0.11 at very high magnetic fields", Nature. DOI: https://doi.org/10.1038/nature07058

Received 13.02.2021

\section{Відомості про авторів / Сведения об авторах / About the Authors}

Бондаренко Ігор Станіславович - Харківський національний університет радіоелектроніки, асистент кафедри біомедичної інженерії, Харків, Україна; email: igor.bondarenko@ nure.ua; ORCID: https://orcid.org/0000-0003-2925-3020.

Бондаренко Игорь Станиславович - Харьковский национальный университет радиоэлектроники, ассистент кафедры биомедицинской инженерии, Харьков, Украина.

Bondarenko Igor - Kharkiv National University of Radio Electronics, Assistant of the Department of Biomedical Engineering, Kharkiv, Ukraine.

Аврунін Олег Григорович - доктор технічних наук, професор, Харківський національний університет радіоелектроніки, завідувач кафедри біомедичної інженерії, Харків, Україна; email: oleh.avrunin@nure.ua; ORCID: https://orcid.org/0000-0002-6312-687X.

Аврунин Олег Григорьевич - доктор технических наук, профессор, Харьковский национальный университет радиоэлектроники, заведующий кафедры биомедицинской инженерии, Харьков, Украина.

Avrunin Oleg - Doctor of Sciences (Engineering), Professor, Kharkiv National University of Radio Electronics, Head of the Department of Biomedical Engineering, Kharkiv, Ukraine.

\section{ПРО ЗБУДЖЕННЯ ЛОКАЛЬНОГО ЕЛЕКТРИЧНОГО СТРУМУ В БІОЛОГІЧНОМУ СЕРЕДОВИЩ}

\footnotetext{
Предметом дослідження в статті є вивчення способу збудження тканин організму людини за допомогою електричного струму. Мета роботи - розробка методу збудження локального струму в тілі людини, що впливає на мікроциркуляцію крові і збудливість локальних ділянок м'язової тканини в перебігу лікувального процесу. У статті вирішуються наступні завдання: створення модельного зразка тканини, обгрунтування методу генерації електричного струму всередині зразка, розробка конструкції системи генерації струму і вимірювання електричного відгуку модельного зразка тканини на виникнення в ній електричного струму, визначення величини і просторового розподілу струму в модельному зразку тканини, порівняння отриманих значень струму 3 відомими і допустимими в медичній практиці його значеннями, визначення переваг запропонованого способу збудження струму в порівнянні 3 традиційним, який використовується в медицині. Використовуються такі методи: аналіз наукових публікацій з предмету дослідження, розрахунок очікуваних параметрів струму в модельному зразку, метод конструювання вузлів системи генерації струму і вимірювання електричного відгуку, експериментальний метод збудження струму і вимірювання відгуку зразка на нього. Отримані наступні результати: обгрунтовано новий акусто-магнітний метод збудження електричного струму в локальних ділянках м'язової тканини, який дозволяє визначати для них оптимальні значення лікувального струму і величину його порогового значення, створені модельні зразки м'язової тканини, обгрунтований магнітогідродинамічний спосіб генерації електричного струму всередині тіла пацієнта, створена конструкція системи генерації струму і вимірювання електричного відгуку модельного зразка тканини на виникнення в ній електричного струму, визначена величина і просторовий розподіл струму в модельному зразку тканини, виконано порівняння отриманих значень струму з відомими і допустимими в медичній практиці його значеннями 1 доведено їх безпечність для людини . Отримано розрахункові співвідношення, що зв'язують величину збудження локального струму $з$ параметрами ультразвукового випромінювання, зовнішнього постійного магнітного поля і біологічного
} 
середовища. Встановлено, що щільність струму, що збуджується в локальній ділянці біологічного середовища, не залежить від частоти ультразвуку і визначається в основному величинами інтенсивності ультразвуку і постійного магнітного поля. Перевагами запропонованого методу збудження струму в порівнянні з традиційним гальванічним методом пропускання струму через шкіру пацієнта є можливість створювати струм в будь-якому необхідному локальній ділянці тканини пацієнта $і$ повна його безпека. Висновки: розроблено та експериментально перевірено на модельних зразках наукові основи нового методу збудження локального струму всередині тіла людини. Використання цього методу може істотно підвищити ефективність лікувального процесу на основі впливу струму на мікроциркуляцію крові в заздалегідь заданих ділянках м'язової тканини і вперше дозволить розрізняти і визначати 3 високою точністю пороги їх збудливості електричним струмом.

Ключові слова: мікроциркуляція крові; поріг збудливості м'язової тканини; модель тканини; магнітна гідродинаміка проводимого розчину; ультразвук; локальний електричний струм.

\section{О ВОЗБУЖДЕНИИ ЛОКАЛЬНОГО ЭЛЕКТРИЧЕСКОГО ТОКА В БИОЛОГИЧЕСКОЙ СРЕДЕ}

Предметом исследования в статье является изучение способа возбуждения тканей организма человека с помощью электрического тока. Цель работы - разработка метода возбуждения локального тока в теле человека, влияющего на микроциркуляцию крови и возбудимость локальных участков мышечной ткани в течении лечебного процесса. В статье решаются следующие задачи: создание модельного образца ткани, обоснование метода генерации электрического тока внутри образца, разработка конструкции системы генерации тока и измерения электрического отклика модельного образца ткани на возникновение в ней электрического тока, определение величины и пространственного распределения тока в модельном образце ткани, сравнение полученных значений тока с известными и допустимыми в медицинской практике его значениями, определение преимуществ предлагаемого способа возбуждения тока по сравнению с традиционным, используемом в медицине. Используются такие методы: анализ научных публикаций по предмету исследования, расчет ожидаемых параметров тока в модельном образце, метод конструирования узлов системы генерации тока и измерения электрического отклика, экспериментальный метод возбуждения тока и измерения отклика образца на него. Получены следующие результаты: обоснован новый акусто-магнитный метод возбуждения электрического тока в локальных участках мышечной ткани, который позволяет определять для них оптимальные значения лечебного тока и величину его порогового значения, созданы модельные образцы мышечной ткани, обоснован магнитогидродинамический способ генерации электрического тока внутри тела пациента, создана конструкция системы генерации тока и измерения электрического отклика модельного образца ткани на возникновение в ней электрического тока, определена величина и пространственное распределения тока в модельном образце ткани, выполнено сравнение полученных значений тока с известными и допустимыми в медицинской практике его значениями и доказана их безопасность для человека. Получены расчетные соотношения, связывающие величину возбуждаемого локального тока с параметрами ультразвукового излучения, внешнего постоянного магнитного поля и биологической среды. Установлено, что плотность тока, возбуждаемого в локальном участке биологической среды, не зависит от частоты ультразвука и определяется в основном величинами интенсивности ультразвука и постоянного магнитного поля. Преимуществами предлагаемого метода возбуждения тока по сравнению с традиционным гальваническим методом пропускания тока через кожу пациента являются возможность создавать ток в любом требуемом локальном участке ткани пациента и полная его безопасность. Выводы: разработаны и экспериментально проверены на модельных образцах научные основы нового метода возбуждения локального тока внутри тела человека. Использование этого метода может существенно повысить эффективность лечебного процесса на основе воздействия тока на микроциркуляцию крови в заранее заданных участках мышечной ткани и впервые позволит различать и определять с высокой точностью пороги их возбудимости электрическим током.

Ключевые слова: микроциркуляция крови; порог возбудимости мышечной ткани; модель ткани; магнитная гидродинамика проводящего раствора; ультразвук; локальный электрический ток.

\section{Бібліографічні описи / Bibliographic descriptions}

Бондаренко І. С., Аврунін О. Г. Про збудження локального електричного струму в біологічному середовищі. Сучасний стан наукових досліджень та технологій в DOI: https://doi.org/10.30837/ITSSI.2021.15.106

Bondarenko, I., Avrunin, O. (2021), "On the excitation of local electric current in the biological environment", Innovative Technologies and Scientific Solutions for Industries, No. 1 (15), P. 106-112. DOI: https://doi.org/10.30837/ITSSI.2021.15.106 